\title{
The effect of the thermoplastic nilon enterprises (valplast) on clove extract (syzygium aromaticum) in various concentrations on the color change
}

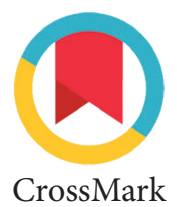

\author{
Niken Wibawaningtyas ${ }^{1 *}$, Dewi Kristiana ${ }^{1}$, Niken Probosari ${ }^{2}$
}

\section{Abstract}

Objective: To investigate the effect of soaking of thermoplastic nylon (valplast) in clove flower extract (syzygium aromaticum) as a denture cleanser with different concentrations: $0.8 \%, 1 \%, 1.2 \%, 1.4 \%$ and $1.6 \%$ to the color change of thermoplastic nylon.

Material and Methods: As many as 30 samples were divided into 6 groups. The sample size was $10 \times 10 \times 1 \mathrm{~mm}$. The first group was immersed in sterile aquades and the other groups were immersed in clove flower extracts with concentrations at $0.8 \%, 1 \%, 1.2 \%, 1.4 \%$ and $1.6 \%$ for 12 days. The light intensity was then measured using densitometer.

Results: One-way ANOVA test results obtained a value of 0.174 $(p>0.05)$, which indicates there is no significant difference between the groups.

Conclusions: Thus it is concluded that darker discoloration occurs in the thermoplastic nylon at a concentration of $1.6 \%$ and lighter discoloration occurs at a lower concentration of $0.8 \%$.
${ }^{1}$ Department of Prosthodontics, Faculty of Dentistry, University of Jember, Jember, Indonesia ${ }^{2}$ Department of Pediatrics, Faculty of Dentistry, University of Jember, Jember, Indonesia

\section{*Corresponding to:}

Niken Wibawaningtyas, Department of Prosthodontics, Faculty of Dentistry, University of Jember, Jember, Indonesia

nikenwibawaningtyas@gmail.com

Received: 15 November 2017 Revised: 25 November 2017 Accepted: 26 November 2017 Available online: 1 December 2017
Keywords: Clove flower extract, Color changes, Thermoplastic nylon

Cite this Article: Wibawaningtyas N, Kristiana D, Probosari N. 2017. The effect of the thermoplastic nilon enterprises (valplast) on clove extract (syzygium aromaticum) in various concentrations on the color change. Journal of Dentomaxillofacial Science 2(3): 180-182. D0l: 10.15562/jdmfs. v2i3.645

\section{Introduction}

The artificial tooth base is a part of the artificial tooth attached to the supporting tissue and where the adhesive of the artificial tooth is applied. ${ }^{1}$ In the denture base material, the denture is of two types: thermo-hardening and thermo-plastic. Thermo-hardening-type denture base material is a type of material that undergoes chemical changes in the formation process, whereas the thermo-plastic-type material (e.g., celluloid, cellulose nitrate, vinyl resin, polycarbonate, and nylon) goes through non-chemical changes in the formation process.

The thermoplastic nylon (valplast) was first introduced in the field of dentistry in $1950 .^{2}$ The use of thermoplastic nylon has both advantages and disadvantages. The advantages include good aesthetics, high flexibility, good transparency and so on; such advantages help with creating a color-matching effect, that is, the denture base color is identical to the color of the underlying tissue; another advantage of valplast is that it is biocompatible and has low water solubility. While the shortcomings of thermoplastic nylon are, among other things, difficulty in hulling and hygroscopy, which can cause discoloration. ${ }^{3}$

The color change that occurs in thermoplastic nylon can be caused by both intrinsic and extrinsic factors. The intrinsic factor is a chemical change in the material itself caused by an imperfect polymerization process, whereas the extrinsic factor is staining caused by the absorption of pigment dyes from the exogenous source of tea, coffee, mouth rinses and artificial dental cleansing solution.

Inadequate patterns of artificial dentures and poor oral hygiene can lead to an increase in the number of candida albicans colonies and cause inflammation of the oral mucosa that affects the denture quality and stability. ${ }^{4}$ This inflammation is called denture stomatitis. To prevent the occurrence of denture stomatitis the patient must be advised to properly maintain denture and oral hygiene. To maintain denture hygiene denture must be cleaned using a cleanser or by brushing the parts of artificial teeth. ${ }^{5}$ Immersion of artificial tooth in denture cleanser is divided into phases:, a. short-term immersion lasting 15-45 minutes during bath or after meals and long-term immersion lasting 6-8 hours at rest. ${ }^{6}$

In the year 2002, WHO had first recommended and validated the use of traditional crops as a drug. ${ }^{7}$ One of them is cloves; cloves contain essential oils (eugenol), flavonoids and tannins that have antifungal properties. ${ }^{8,9}$ In addition to having the antifungal properties, flavonoids and tannins also have natural plant pigments that can cause color changes. Based on previous research on the effect 
of clove flower extract with concentrations at $0.8 \%$, $1 \%, 1.2 \%, 1.4 \%$ and $1.6 \%$ in reducing the amount of C. albicans in denture.

Based on the parameters discussed above, the present study was carried out to study the effect the immersion of valplast in clove flower extract (syzygium aromaticum) with concentrations of $0.8 \%, 1 \%, 1.2 \%, 1.4 \%$ and $1.6 \%$ on the color change of valplast.

\section{Material and Methods}

This research is a laboratory-based experiment with post-test control group design. The materials used in this research include nylon thermoplastic (valplast), sterile aquades and clove flower extract (syzygium aromaticum) with various concentrations, at $0.8 \%, 1 \%, 1.2 \%, 1.4 \%$ and $1.6 \%$. The tool for making samples is the master model of red night cavex, whereas densitometer was used to measure the intensity of light.

The research began with the making of clove flower extract by maceration of cloves and subsequently the evaporation process to dry the clove flowers. The dried clove flowers were dried and blend to to make a powder of clove flowers (simplicia). Simplicia is put into a sealed and masked bottle (maceration) filled with 1.5 liters of $96 \%$ pure ethanol until all the parts were submerged. The saturation was carried out at room temperature for \pm 3 days and then the maceration was filtered using a Buchner funnel. Filtrate and dregs were separated and then the waste was put to remaseration for 24 hours in 1.5 liters of $96 \%$ pure ethanol5 liters. The obtained filtrate was then concentrated with a rotary evaporator at a temperature of no more than $50^{\circ} \mathrm{C}$ and evaporated in a vacum, separating the solvent and $96 \%$ ethanol from clove flower extract; thus, $100 \%$ pure clove flower extract was obtained and diluted to create clove flower extract in the following concentrations: $0.8 \%, 1 \%, 1.2 \%, 1.4 \%$ and $1.6 \%$.

The experiment was continued further, to manufacture thermoplastic nylon samples (valplast). The method of preparation involves the following steps: the master model of red night square and sprue were planted in hard casts; after the casts were hardened the cuvette was opened, smeared with a separator material and allowed to dry. In contrast to acrylics, the molding is carried out by melting the thermoplastic nylon in the cartridge at a temperature of $248.8-265.5^{\circ} \mathrm{C}$ in an electric furnace and injection molding into the mold space.

The size of the finished sample plate was $10 \times 10 \times 1 \mathrm{~mm} ; 30$ samples were prepared. The samples were divided into six groups: the first group was soaked in sterile aquades and was the control group and the other groups were treatment groups and samples in these groups were soaked in clove flower extract in different concentrations at $0.8 \%$, $1 \%, 1.2 \%, 1.4 \%$, and $1.6 \%$ and were kept immersed in the extract for 12 days. After the completion of this process, the samples were taken out of the extracts in which they were immersed and were rinsed with sterile aquades and dried; in the next step, the light intensity was measured using a densitometer. The data obtained were tabulated. Data analysis was performed using one-way ANOVA with $95 \%$ significance level.

\section{Results}

Figure 1 illustrates the mean results of light intensity measurements of both the control group thermoplastic nylon plates immersed in sterile aquades and the treatment group samples immersed for 12 days in clove flower extracts with different concentrations, $0.8 \%, 1 \%, 1.2 \%, 1.4 \%$ and $1.6 \%$.

Based on the measurement of light intensity on thermoplastic nylon plate after they were soaked in clove flower extract, data analysis was carried out using Kolmogorov-Smirnov test for assessment of data normality and levene's test for assessing the homogeneity of data gathered from the experiments. Both test results yielded a probability value of $p>0.05$, which shows the data are normal and homogeneously distributed. After it was confirmed that the data were normal and homogeneously distributed, further analysis was carried out using one-way ANOVA which yielded a significance value of $0.174(p>0.05)$. Thus, we concluded there is no significant difference between the color changes of thermoplastic nylon plates used for the control group and those used for the treatment groups.

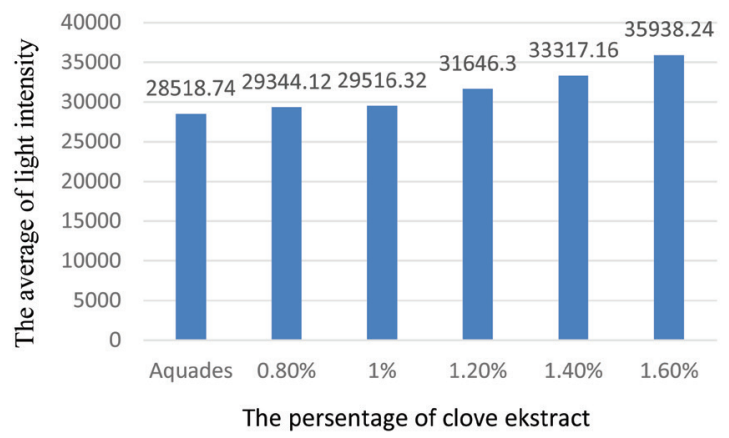

Figure 1 Graph showing the average light intensity of thermoplastic nylon plates after they were soaked in clove flower extract and sterile aquades 


\section{Discussion}

Artificial denture base materials are widely used in dentistry and one of them that is frequently used is thermoplastic nylon. It has both advantages and disadvantages. One drawback to using thermoplastic nylon is that it is difficult to process in hybrid and hygroscopic procedures where it easily absorbs water from the surrounding environment. ${ }^{10,11}$ This characteristic can cause color changes in the denture base. ${ }^{12}$

In this study, two sets of thermoplastic nylon samples were used: one set of samples were immersed in sterile aquades and retained as control group samples and five sets of samples were retained as treatment group samples and were immersed in clove flower extract in different concentrations at $0.8 \%, 1 \%, 1.2 \%, 1.4 \%$ and $1.6 \%$. Both sets of samples were immersed in their respective extracts for 12 days, which is equivalent to soaking for 3 years.

The result of light intensity measurement in the control group and in the treatment group showed that the color in the thermoplastic nylon became darker and the light intensity was higher in each treatment group. The increase in light intensity value is due to the chromophore compound one of the benzene groups contained in the flavonoid and tannin compounds, and the presence of this compound causes the increase of UV-Vis absorption by the thermoplastic nylon plate. However, the difference in the mean value of light intensity between the treatment group samples that used extracts of different concentrations is not too large. This is because the concentration difference in the treatment group is only $0.2 \%$.

Increased light intensity showed a darker color in the thermoplastic nylon plates soaked in artificial tooth cleanser of clove flower extract; flavonoids and tannins in the clove flower extract are natural plant dyes, which led to a darker color in the treatment group samples. ${ }^{9}$ Flavonoids and tannins enter into microporosities that form during an inopportune injection molding process of thermoplastic nylon. ${ }^{13}$ Flavonoids and tannins enter into the microporosities of diffuse thermoplastic nylon.

Flavonoids and tannins are phenol groups, where phenols are acidic because they have a lower $\mathrm{pH}$ than aquades and alcohols. The chemical formula of this compound is $\mathrm{C} 6 \mathrm{H} 5 \mathrm{OH}$, and its structure has a hydroxyl group (-OH) attached to the phenyl ring. In the chemical formula of phenol, $\mathrm{C}$ can more strongly bind to $\mathrm{O}$ than it can to $\mathrm{H}$; thus, $\mathrm{H}$ ions are easily oxidized and become acidic. The oxidation of $\mathrm{H}$ ion causes the phenol compound to dissolve into an anion of phenoxide $\mathrm{C} 6 \mathrm{H} 5 \mathrm{O}$ - and the cation of $\mathrm{H}+$. This $\mathrm{H}+$ cation readily breaks the $\mathrm{OH}$ bond on the polyamide chain so that this polyamide chain becomes shorter and causes a decrease in the physical properties of the thermoplastic nylon, one of which is the discoloration of the thermoplastic nylon. Color changes can also occur on account of the length of denture wear. Artificial teeth show physical changes that cause discomfort in use within 1 to 5 years.

\section{Conclusion}

The change of color of the thermoplastic nylon plate is indicative of the highest increase in light intensity on the thermoplastic nylon plates soaked in artificial denture cleanser of clove flower in $1.6 \%$ concentration, whereas the lowest light intensity was observed on the thermoplastic nylon plates soaked in clove flower extract with $0.8 \%$ concentration. Thus it is concluded that clove flower extract with $0.8 \%$ can more effectively prevent discoloration of denture base compared to artificial denture cleansers.

\section{Conflict of Interest}

The authors report no conflict of interest.

\section{References}

1. Blarcom CW. The glossary of prosthodontic term 8th ed. J Prosthet Dent 2005;94: 31 .

2. DiTolla M. Valplast flexible, esthettic partial dentures. Chairside Perspective 2004;5: 1-4.

3. Hargeaves AS. Nylon AS a denture base material. Dent Pract Dent Rec 1997;22: 122-128.

4. Jawetz E, Melnick JL, Adelberg EA. Mikrobiologi kedokteran. 20th ed. Jakarta: EGC; 1996.

5. Parnaadji R. Bahan-bahan pembersih gigi tiruan untuk mencegah denture stomatitis. Stomatognatic JKG Unej 2005;1: 12-15.

6. Budzt-Jogersen E. Materials and methods for cleaning denture. J Prost Dent 1979;42: 619-622.

7. Wahyuningtyas E. Pengaruh ekstrak graptophyllum pictum terhadap pertumbuhan candida albicans pada plat gigi tiruan resin akrilik. J Indo of Dentist 2008;13: 187-191.

8. Bhowmik D, Kumar KP, Yadav A, et al. Recent trend in India traditional herbs syzygium aromaticum and its health benefit. J Pharmacog Phytochem 2012;1: 13-22.

9. Mu'anisa A, Wresdiyati T, Kusumorini N, et al. Aktivitas antioksidan ekstrak daun cengkeh. J Veterin 2012;13: 272-277.

10. Durkan R, Ayas AE, Bagis B, et al. Comparative effect of denture cleansers on physical properties of polyamide and polymethyl methacrylate base polymers. J Dent Mat 2013;32: 367-375.

11. Takabayashi Y. Characteristic of denture thermoplastic resin for non-metal claps denture. Dent Mat J 2010;29: 353-361.

12. Shamnur SN, Jagadeesh KN, Kalavathi SD, et al. Flexible denture an alternate for rigid denture. J Dent Sci Res 2008; 1: 74-79.

13. Negrutiu M, Sinesca C, Romanu M, et al. Thermoplastic resin for flexible framework removable partial denture. Timisoara Med J 2005;55: 295-299.

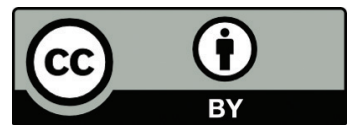

This work is licensed under a Creative Commons Attribution 